\title{
EFFECT OF ELEVATED TEMPERATURE ON WEED SEED GERMINATION IN PADDY SOIL SEED BANK
}

\author{
R.M.U.S. Bandara*, T.K. Ilangakoon, H.M.M.K.K.H. Dissanayaka, Y.M.S.H.I.U. De \\ Silva, C.H.Piyasiri and D.M.C.B. Dissanayaka \\ Rice Research and Development Institute, Batalagoda, Ibbagamuwa, Sri Lanka
}

Email:*rmusbandara@gmail.com

\begin{abstract}
A pot experiment was conducted employing CRD to study how weed seeds are germinated in paddy soil seed bank under elevated temperatures in 2015/16 maha season. Pots were filled with top soils up to $12 \mathrm{~cm}$ and kept at 04 different temperatures namely $27^{\circ} \mathrm{C}, 30^{\circ} \mathrm{C}, 35^{\circ} \mathrm{C}$ and $40^{\circ} \mathrm{C}$ in a controlled growth chamber. Relative humidity of the growth chamber was maintained at $80 \%$. Seedling counts were recorded at 10 days intervals up to one month. Results revealed that Counts of Seedling Germinated (CSG) of all types of weeds (Grasses, Sedges and Broadleaves) showed a significant increment at elevated temperature of $35^{\circ} \mathrm{C}$. The CSG of sedges was not significantly increased at $35^{\circ} \mathrm{C}$. But the CSG of grasses and broadleaves types of weeds showed a significant increment at elevated temperature of $35^{\circ} \mathrm{C}$. Beyond $35^{\circ} \mathrm{C} \mathrm{CSG}$ showed a significant decline in all types of weeds. Elevated temperature up to $35^{\circ} \mathrm{C}$ causes significant increment in count of seedling germinated and beyond $35^{\circ} \mathrm{C}$ it causes significant decline in count of seedling germinated in tested paddy soils under $80 \% \mathrm{RH}$ level. There is a potential of increasing populations of weed species like Echinochloa crus-galli, Leptochloa chinensis, Lindernia rotundifolia and Monochoria vaginalis in rice growing fields under elevated temperatures.
\end{abstract}

Keywords: Elevated Temperature, Germination, Soil Seed-Bank

\section{Introduction}

The temperature and light are the most important environmental factors that promote the seed germination in the soil when water is available (K. C. Gairola et al., 2011). For most of the plants, if the light and water are available, the temperature of the soil determines the fraction of the germinated seeds and the rate of the germination (K. C. Gairola et al., 2011). The germination of the seeds is a complex process where several reactions and individual factors are involved, every process affected by the temperature (K. C. Gairola et al., 2011). The temperature affects the germination and the state of dormancy of the seeds and the seasonal changes of the dormancy state of the seeds of some species is directly related to the seasonal temperature changes. Some species can present the seeds with the light requirement for the germination at one temperature and in another, the light insensitivity (K. C. Gairola et al., 2011). Seed germination is affected by the ecological conditions prevailing in the habitat; it depends on several environmental conditions such as light, temperature, moisture germination media (K. C. Gairola et al., 2011). It is well known that seed of certain species have different temperature responses according to variety and provenances and also reasonable to believe that these responses are adaptive success or failure of a population in a particular environment depends on the way of its germination responses fit in to the ecological conditions of the habitat (K. C. Gairola et al., 2011). Thus in most of the seeds, the rate of germination are strongly governed by temperature (K. C. Gairola et al., 2011). In order to study the weed seeds germination with elevated temperatures this study was conducted. 


\section{Materials and Methods}

A pot experiment was conducted within a growth chamber at Rice Research and Development Institute, Batalagoda during maha2015/2016 season. Soil was collected from a paddy field and mixed well. Black coloured plastic pots having the height of $15 \mathrm{~cm}$ and inner mouth diameter of $15 \mathrm{~cm}$ were filled with the soil up to $12 \mathrm{~cm}$ and kept at 04 different temperatures namely $27^{\circ} \mathrm{C}$ (room temperature), $30^{\circ} \mathrm{C}, 35^{\circ} \mathrm{C}$ and $40^{\circ} \mathrm{C}$ in a controlled growth chamber for 10days. Relative humidity of the growth chamber was maintained at $80 \%$. Seedling counts were recorded. Data were analysed adopting ANOVA using SAS software package. Counts data were square root transformed and checked for the normality prior to analysis.

\section{Results and Discussion}

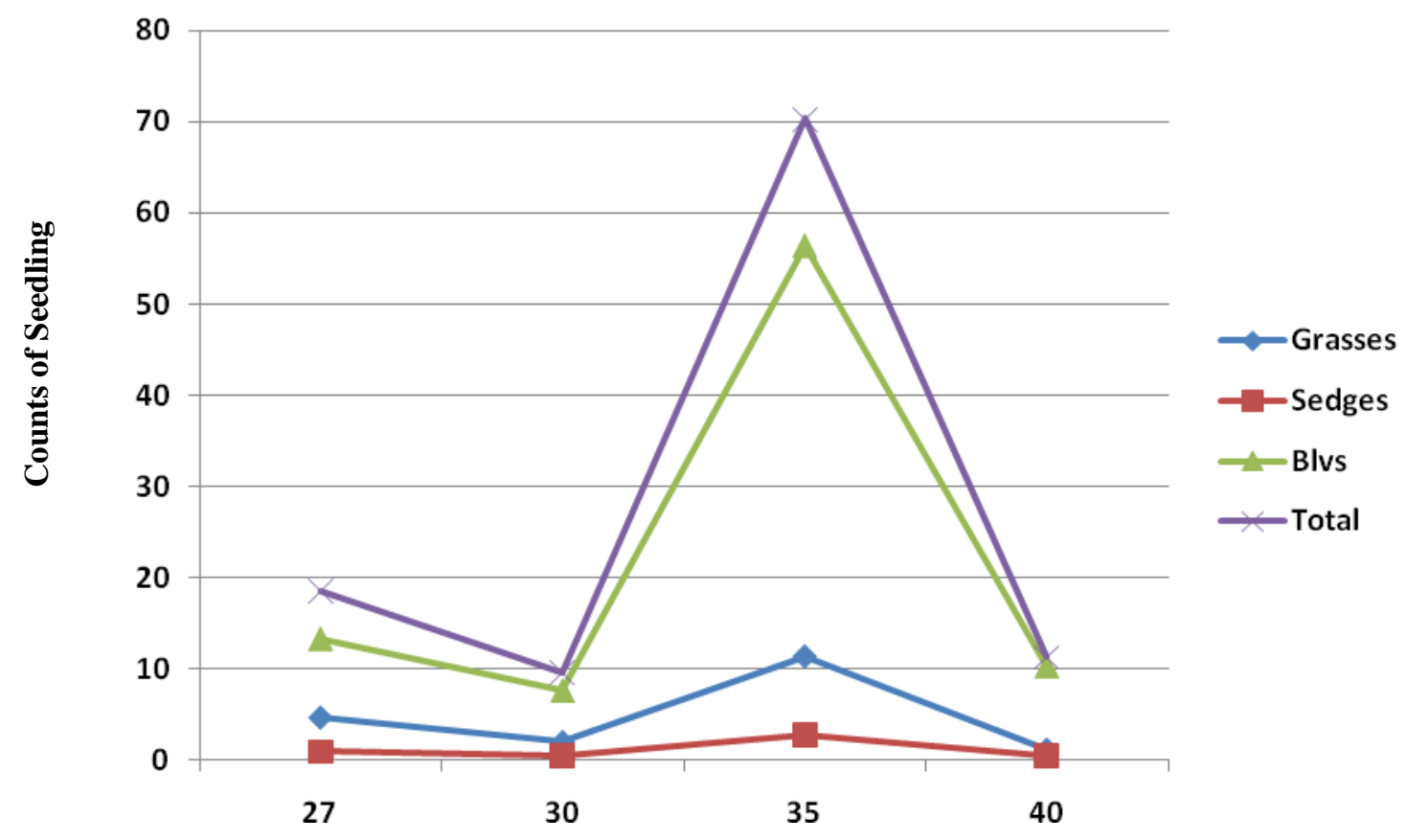

Temperature in Centigrade

Figure 01. Count of Seedlings Germinated (CSG) under different temperatures

As shown in figure $01 \mathrm{CSG}$ of all 03 types of weeds showed an increment at elevated temperature of $35^{\circ} \mathrm{C}$. The CSG of sedges was not significantly increased at $35^{\circ} \mathrm{C}$. But the CSG of grasses and broadleaves types of weeds showed a significant increment at elevated temperature of $35^{\circ} \mathrm{C}$. Beyond $35^{\circ} \mathrm{C} \mathrm{CSG}$ showed a significant decline in all 03 types of weeds. Gairola et al. (2011) reported that Speed of germination was recorded highest at $35^{\circ} \mathrm{C}$ $(8.40 \pm 0.44)$ and lowest at $22^{\circ} \mathrm{C}(0.11 \pm 0.10)$. Different species showed different patterns of germination. Ludwigia octovalvis seedling counts were decreasing with increasing temperatures. Echinochloa crus-galli seedling counts were increasing with increasing temperatures. Seedling counts of Leptochloa chinensi, Lindernia rotundifolia and Monochoria vaginalis were increasing with increasing temperature up to $35^{\circ} \mathrm{C}$ and decreased beyond $35^{\circ} \mathrm{C}$. Seedling counts of Cyperus deformis were decreasing with increasing temperature up to $30^{\circ} \mathrm{C}$ and then increasing with increasing temperatures. It is concluded that different weed species behave differently with increasing temperatures. 


\section{Conclusion}

It is concluded that different weed species behave differently with increasing temperatures. Elevated temperature up to $35^{\circ} \mathrm{C}$ causes significant increment in count of seedling germinated and beyond $35^{\circ} \mathrm{C}$ it causes significant decline in count of seedling germinated in tested paddy soils under $80 \% \mathrm{RH}$ level. There is a potential of increasing populations of weed species like Echinochloa crus-galli, Leptochloa chinensi, Lindernia rotundifolia and Monochoria vaginalis in rice growing fields under elevated temperatures.

\section{References}

Gairola, K. C., Nautiyal, A. R. and Dwivedi, A. K., 2011, Effect of Temperatures and Germination Media on Seed Germination of Jatropha Curcas Linn. ADVANCES IN BIORESEARCH, Volume 2, Issue 2, December 2011: $66-71$

Gorai M, Neffati M. 2007. Germination responses of Reaumuria vermiculata to salinity and temperature. Annals of Applied Biology 151: 53-59.

Grice AC, Westoby M. 1987. Aspects of the dynamics of the seed banks and seedling populations of Acacia victonae and Cassia spp. In western New South Wales. Australian Journal of Ecology 12, 209-215.

Gutterman Y. 2002. Survival Strategies of Annual Desert Plants: Adaptations of Desert organisms. Springer, Berlin.

Huang Z, Zhang XS, Zheng GH, Gutterman Y. 2003. Influence of light, temperature, salinity and storage on seed germination of Haloxylon ammodendron. Journal of Arid Environment 55: 453-464.

Jame YW, Cutforth HW. 2004. Simulating the effects of temperature and seeding depth on germination and emergence of spring wheat. Agricultural and Forrest Meteorology 124: 207-218.

Koocheki A, Zarif Ketabi H. 1996. Determination of optimum temperature for seed germination and the evaluation of the effects of salinity and water deficit on some forage species. Journal of Biaban. 1(1): 45-56.

Li L, Tsao R, Liu Z, Liu S, Yang R, Young JC, Fu Z. 2005. Isolation and purification of acteoside and isoacteoside from (Plantago psyllium L.) by high-speed counter-current chromatography. Journal of chromatography A 1063(1): 161-169.

Loka DA, Oosterhuis DM. 2010. Effect of high night temperatures on cotton respiration, ATP levels and carbohydrate content. Environmental and Experimental Botany 68:258-263. 